\title{
The GLABRA2 gene encodes a homeo domain protein required for normal trichome development in Arabidopsis
}

\author{
William G. Rerie, ${ }^{1,3}$ Kenneth A. Feldmann, ${ }^{2}$ and M. David Marks ${ }^{1,4}$ \\ ${ }^{1}$ School of Biological Sciences, University of Nebraska-Lincoln, Lincoln, Nebraska 68588-0118 USA; ${ }^{2}$ Department of Plant \\ Sciences, University of Arizona, Tucson, Arizona 85712 USA
}

The GLABRA2 gene (GL2) is one of several genes known to have a role in trichome development in Arabidopsis. Mutations at this locus result in abnormal trichome expansion. We have identified several gl2 mutants from a T-DNA-mutagenized population of plants. The T-DNA insert in one of the mutant lines cosegregated with the recessive g12 phenotype and thus served as a molecular tag to isolate genomic DNA at the putative GL2 locus. RFLP analysis of the segregating population and subsequent molecular complementation experiments established that the GL2 gene had been cloned. The predicted polypeptide from one of the ORFs contained on this fragment showed significant identity to the homeo domain sequence. The construction of a full-length cDNA by RT-PCR confirmed the presence of a homeo box in the GL2 gene and showed that it is substantially different from other recently cloned homeo box genes in plants. The expression pattern of $G L 2$, as demonstrated by in situ hybridization, indicated that the gene is expressed in trichome progenitor cells and at stages associated with trichome development. This suggests that $G L 2$ may regulate events required for the directional cell expansion observed during trichome formation.

[Key Words: Arabidopsis; GLABRA2 gene; trichome development; homeo domain protein; homeo box]

Received March 22, 1994; revised version accepted May 10, 1994.

The elaboration of surface hairs or trichomes is a characteristic shared by many plant species. Trichome form, density, and location on the plant body often serve as distinguishing traits in plant systematics (GómezCampo and Tortosa 1974). Trichomes are generally associated with the epidermal surface of leaves, petioles, and stems, although developmentally they are not restricted to these plant organs as demonstrated by formation of pollen collecting hairs on the style of Campanula (Nyman 1993) or by the differentiation of trichomes on the inflorescence of Chrysanthemum (Vermeer and Peterson 1979|. In each instance, a subset of cells derived from the meristematic protoderm differentiates into a cell type that undergoes marked cell enlargement away from the epidermal surface.

The adaptive value of plant pubescence is not always apparent, although it is probable that trichome function varies between species. In desert plants, a dense covering of trichomes increases leaf reflectance, thereby moderating leaf surface temperature as well as photosynthetic and transpiration rates (Ehkeringer 1984). A mutation suppressing trichome development on the anthers of to-

\footnotetext{
${ }^{3}$ Present address: Plant Research Centre, Agriculture Canada, Ottawa, ON. K1A 0C6, Canada.

${ }^{4}$ Corresponding author. Present address: Department of Genetics and Cell Biology, University of Minnesota, St. Paul, Minnesota 55108 USA.
}

mato causes their normal connate form to separate from around the pistil, resulting in reduced self-pollination and lower fruit yields (Rick 1947). Also, in many species, leaf and stem trichomes are glandular cells capable of synthesizing a variety of secondary metabolites that may play a role in the plant's defense against herbivory (Wagner 1991).

We are using trichome development in Arabidopsis thaliana as a model to address questions regarding the control of cell fate and cell differentiation in plants (Marks et al. 1991). The utility of the model is enhanced by the availability of many mutants with altered trichome development. Genetic analyses indicate that at least 21 distinct loci are involved in Arabidopsis trichome development (Hülskamp et al. 1994; Marks and Esch 1994). Many of these genes have been placed on the genetic map; however, in most instances, their molecular function remains unknown.

The trichome gene loci can be placed into one of two classes. Mutations in one class prevent the establishment of trichome cell fate, producing plants with glabrous leaves and stems. Mutations at the TTG and GL1 loci are representative of this phenotype (Koornneef 1981; Oppenheimer et al. 1992). The second type of mutation affects cell differentiation resulting in the formation of trichomes with altered morphology. Because trichome precursor cells in Arabidopsis differentiate with- 
out cell division, the mutations in this class of loci probably identify genes required for proper trichome expansion. Examples of these putative cell expansion mutants include dis1, dis2, gl2, gl3, and stl1 (Haughn and Somerville 1988; Marks and Esch 1992, 1994).

Insertional mutagenesis using Agrobacterium T-DNA has proven to be an effective means of cloning genes identified only by their mutant phenotype (Feldmann 1991). Previously, we have used T-DNA tagging to isolate and clone the GL1 gene (Herman and Marks 1989; Marks and Feldmann 1989). Here, we report the use of T-DNA tagging to clone GLABRA2 (GL2), a gene involved not only in the morphological development and maturation of Arabidopsis trichomes but also for the normal production of a seed coat mucilage (Koornneef et al. 1982). DNA sequence analysis showed that GL2 encodes a homeo domain (HD), a motif that is associated with transcription factors involved in animal and plant development (Affolter et al. 1990; Gehring et al. 1990; Vollbrecht et al. 1991).

\section{Results}

\section{Trichome phenotype of wild-type and the gl2 mutant}

Trichomes in A. thaliana [ecotype Wasselewskija (WS)] are evenly distributed over the adaxial surface of the rosette leaves but are absent from the cotyledons (Fig. 1A). Their characteristic stellate form consists of a stalk that generally diverges into three branches (Fig. 1C). In contrast, the first leaf pair of plants homozygous for the gl2 mutation appear virtually glabrous (Fig. 1B). These leaves, however, do produce aborted trichomes that expand laterally along the leaf surface (Fig. 1D). Later ro- sette leaves of the mutant develop rudimentary trichomes that often appear as short spikes (see Fig. 2F).

Trichomes develop from protodermal tissue on the leaf primordia of young seedlings. In wild-type plants, incipient trichomes are seen as individual cells swelling and expanding outward, perpendicular to the leaf surface (Fig. 2A,B). Shortly after cell expansion begins, protuberances form at the distal end of the cell from which the branches emerge (Fig. 2C). The epidermal cells around the base of the trichome acquire a distinct morphology during development, and they may provide structural support for the mature trichome. Trichome maturation is also associated with changes in cell wall character; the walls become rigid and develop small surface papillae (Fig. 1C). X-ray microanalysis performed in conjunction with scanning electron microscopy (SEM) showed that mature trichomes have a high calcium content (possibly as calcium carbonate), which appears to be associated with the surface papillae (E. Delhaize, pers. comm.).

The timing of trichome initiation in the mutant does not seem to be altered relative to wild-type plants (Fig. 2D). However, expansion of the nascent trichome cell is less constrained and lateral expansion is greatly enhanced (Fig. 2E, cf. size bar with B). This was particularly evident on the first pair of rosette leaves, where cell expansion occurs almost exclusively along the surface of the leaf lamina, producing the elongated cell shown in Figure 1D. Immature trichomes from later rosette leaves do expand upward, but their development is aborted, resulting in an array of stubs or short spikes on the mature gl2 leaf (Fig. 2F). Many of the aborted trichomes are no longer associated with the epidermal support cells or exhibit the surface papillae seen on wild-type trichomes. In addition to these morphological changes, trichome density is also reduced.
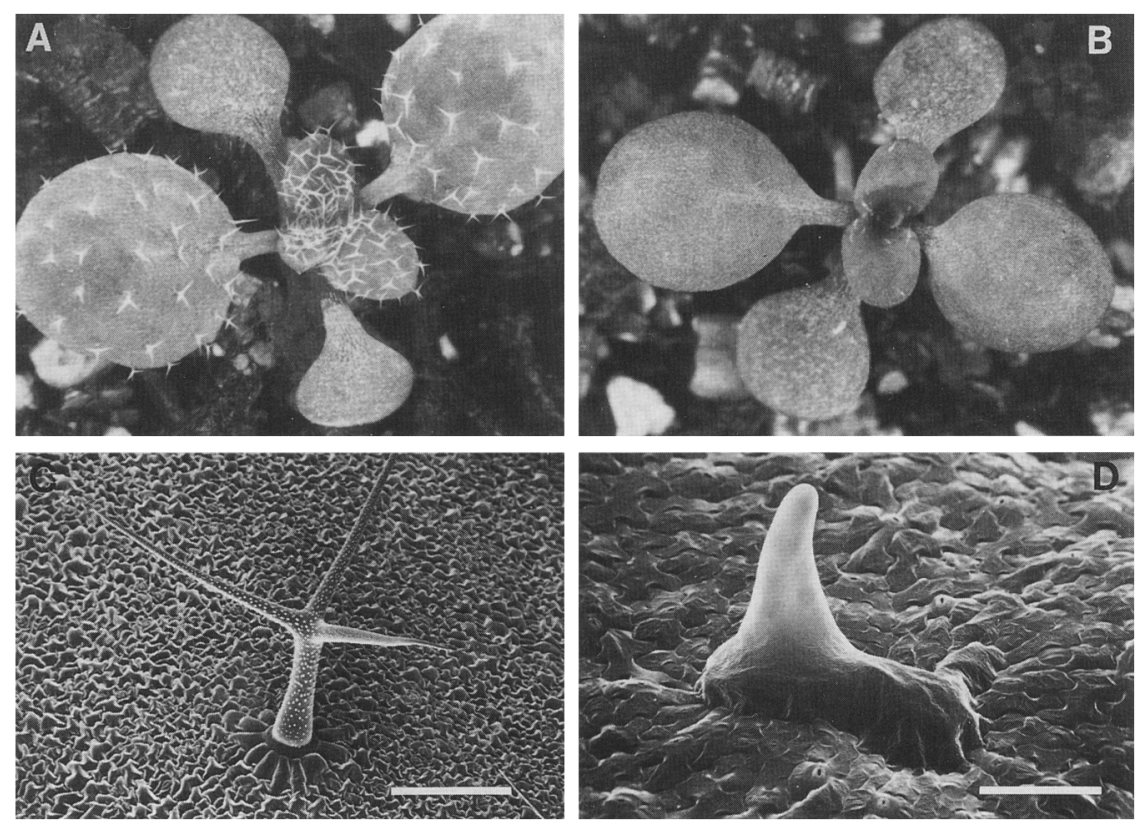

Figure 1. The effect of the gl2 mutation on Arabidopsis trichomes. Seedlings are shown at the four- to five-leaf stage from a wild-type $(A)$ and homozygous g12 mutant $(B)$. Shown are scanning electron micrographs of trichome morphology on the first leaf of wild-type $(C)$ and homozygous g12 mutant $(D)$ plants. Size bars, $200 \mu \mathrm{m}$ (C); $40 \mu \mathrm{m}(D)$. 
Rerie et al.
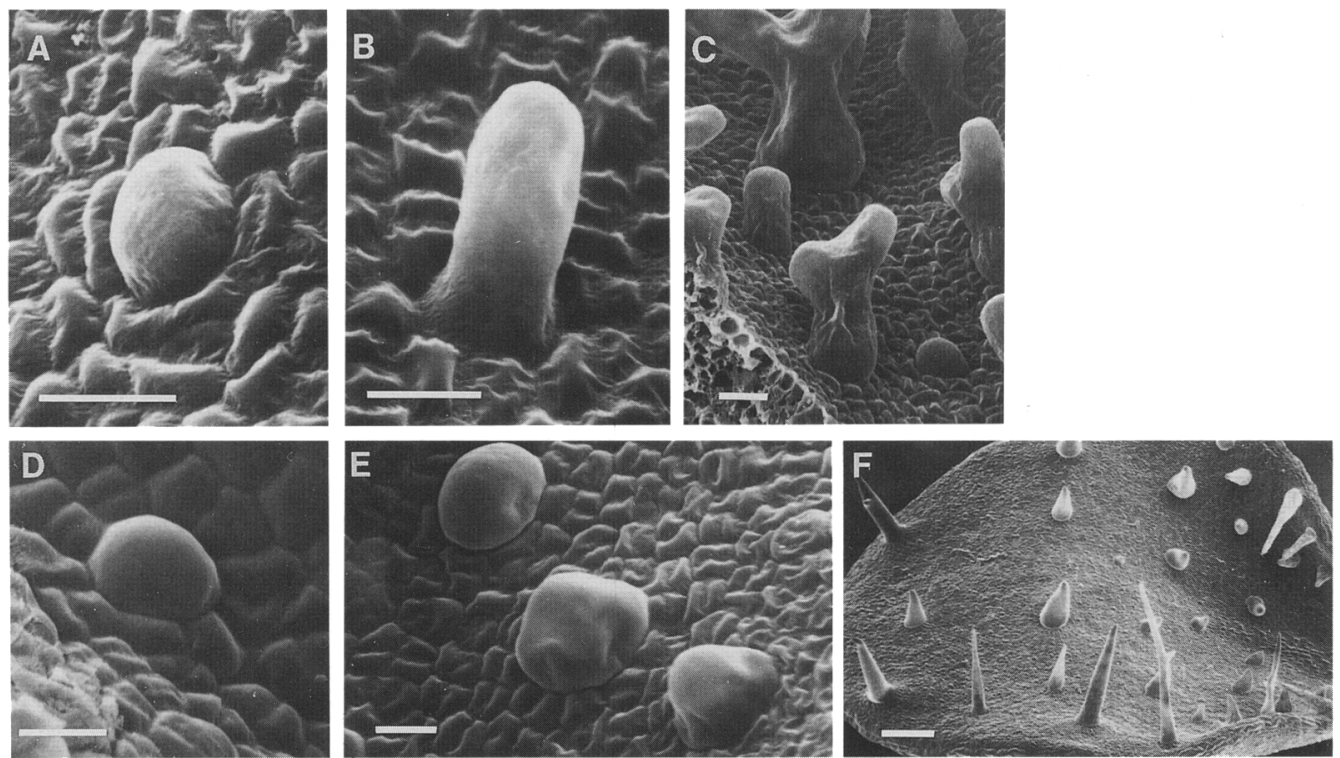

Figure 2. Trichome development in Arabidopsis. Scanning electron micrographs are shown of developing trichomes on the fourth leaf of wild-type $(A-C)$ and $g l 2$ mutant $(D-F)$ plants. Size bars, $10 \mu \mathrm{m}\langle A-E) ; 100 \mu \mathrm{m}(F)$.

The g12 mutation affects the synthesis of seed coat mucilage

During the course of normal embryogenesis, the maternally derived integuments develop into a protective seed coat or testa. In Arabidopsis, a mucopolysaccharide or mucilage layer is produced by the outer integument cells as part of their normal differentiation program (Van Caeseele et al. 1981; Harris 1991). The mucilage appears to accumulate on the seed surface in tufts that are linked by a network of strands (Fig. 3B). Hydration of the mucilage allowed it to be visualized as a halo around wild-type seeds (Fig. 3A).

As noted previously by Koornneef (1981), plants homozygous for the gl2 mutation fail to accumulate a mucilage layer around the seed, as indicated by the absence of a halo (Fig. 3C). The seed coat surface itself appears unaltered by the mutation, with the exception that the mucilage tufts are absent (Fig. 3D).

\section{A T-DNA insertion is closely linked to the gl2-2 allele}

Seed transformation of Arabidopsis by Agrobacterium tumefaciens has been used to generate large numbers of transformants, some of which show novel phenotypes attributable to gene inactivation by the integrating T-DNA (Feldmann and Marks 1987; Feldmann 1991). We screened a population of transformed Arabidopsis and identified a number of plants that displayed abnormal trichome phenotypes. Allelism tests indicated that four individual lines failed to complement the $\mathrm{gl} 2 \mathrm{mu}$ tation (Koornneef et al. 1982). Data from a genetic analysis suggested that one of the lines contained a T-DNA insert linked to the g12 locus. This was shown by following kanamycin resistance $\left(\operatorname{Kan}^{r}\right)$, which is a dominant selectable marker for the T-DNA, among a population of plants segregating for the $g 12$ phenotype. Individuals heterozygous for the recessive g12 mutation segregated progeny with a ratio of $1: 2: 1 \mathrm{Kan}^{\mathrm{r}}$ mutant/2 $\mathrm{Kan}^{\mathrm{r}}$ wild-type/ kanamycin sensitive $\left(\mathrm{Kan}^{\mathrm{s}}\right)$ plant, indicating that the T-DNA was linked to the g12 mutation (Table 1). Additional support for linkage was provided by the observation that all progeny from 15 individuals homozygous for gl2 were $\mathrm{Kan}^{\mathrm{r}}$. We refer to this T-DNA-inactivated allele
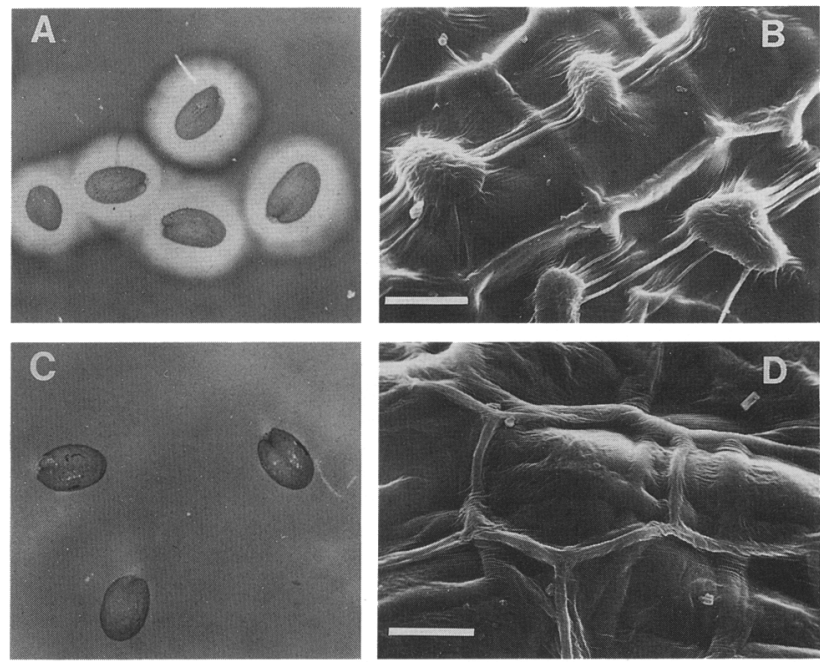

Figure 3. The effect of the gl2 mutation on seed coat mucilage. Mature seeds from wild-type $(A)$ and from plants homozygous for the gl2 mutation $(C)$ were suspended in diluted India ink to visualize the presence of mucilage around the seed. Topography of the mature seed coat is shown in wild-type $|B|$ and the gl2 mutant $(D)$ as seen by scanning electron micrography. Bars, $10 \mu \mathrm{m}$. 
Table 1. Segregation of the gl2 phenotype among progeny from selfed $\mathrm{Kan}^{T}$ plants

\begin{tabular}{|c|c|c|c|c|c|c|c|}
\hline \multicolumn{4}{|c|}{ Segregation of $\operatorname{Kan}^{\mathrm{r}}$ with normal trichomes ${ }^{\mathrm{a}}$} & \multicolumn{4}{|c|}{ Segregation of $\operatorname{Kan}^{x}$ plants with aborted trichomes } \\
\hline & $\underset{\text { aborted }}{\operatorname{Kan}^{\mathrm{r}}}$ & $\begin{array}{c}\mathrm{Kan}^{\mathrm{r}} \\
\text { normal }\end{array}$ & $\mathrm{Kan}^{\mathrm{s}}$ & & $\begin{array}{c}\operatorname{Kan}^{\mathrm{r}} \\
\text { aborted }\end{array}$ & $\begin{array}{c}\operatorname{Kan}^{\mathrm{r}} \\
\text { normal }\end{array}$ & $\mathrm{Kan}^{\mathrm{s}}$ \\
\hline $\mathrm{N}-1$ & 21 & 35 & 19 & A-1 & 102 & 0 & 0 \\
\hline $\mathrm{N}-2$ & 23 & 48 & 23 & A-2 & 105 & 0 & 0 \\
\hline $\mathrm{N}-3$ & 21 & 37 & 18 & A-3 & 104 & 0 & 0 \\
\hline $\mathrm{N}-4$ & 24 & 46 & 19 & A-4 & 104 & 0 & 0 \\
\hline N-5 & 54 & 107 & 43 & A-5 & 107 & 0 & 0 \\
\hline
\end{tabular}

Segregation data shown for 5 of 15 individual $\operatorname{Kan}^{\mathrm{r}}$ plants tested with either normal $(\mathrm{N})$ or aborted (A) trichomes.

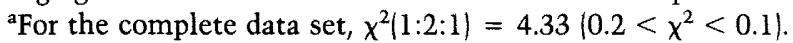

as g12-2 in distinction from the original allele $|g 12-1|$ identified by Koornneef et al. (1982).

\section{Cloning the GL2 gene and its complementation of the $\mathrm{gl} 2$ mutation}

The T-DNA (pGV3850:pAK1003) used in the mutagenesis contains two copies of the plasmid pBR322. Either plasmid can be used to directly clone genomic DNA flanking the insertion site by plasmid rescue in Escherichia coli (see Materials and methods; Feldmann 1992). Two identical clones were rescued that appeared to be derived from the right border junction of the T-DNA insert. One of the plasmids (3E5) was labeled and used to probe a Southern blot containing EcoRI-digested genomic DNA from wild-type plants and from individual plants segregating for the g12-2 allele. It was determined that 3E5 hybridized as a single band in wild-type DNA and, furthermore, it detected an RFLP that cosegregated with the mutant allele (data not shown).

To establish unequivocally that the T-DNA had disrupted the GL2 gene, molecular complementation experiments were performed. One of the gl2 lines identified in the original screen subsequently segregated the $\mathrm{Kan}^{\mathrm{r}}$ phenotype away from the mutant allele. Plants homozygous for this allele, referred to as g12-3, had an identical phenotype to g12-2 and were used for the complementation experiments. Genomic DNA isolated from plasmid 3 E5 was used to screen an Arabidopsis genomic library (ecotype WS). Several positive $\lambda$ clones were isolated and mapped with respect to the T-DNA insertion site and the rescued plasmid. Three overlapping $\lambda$ clones cover-

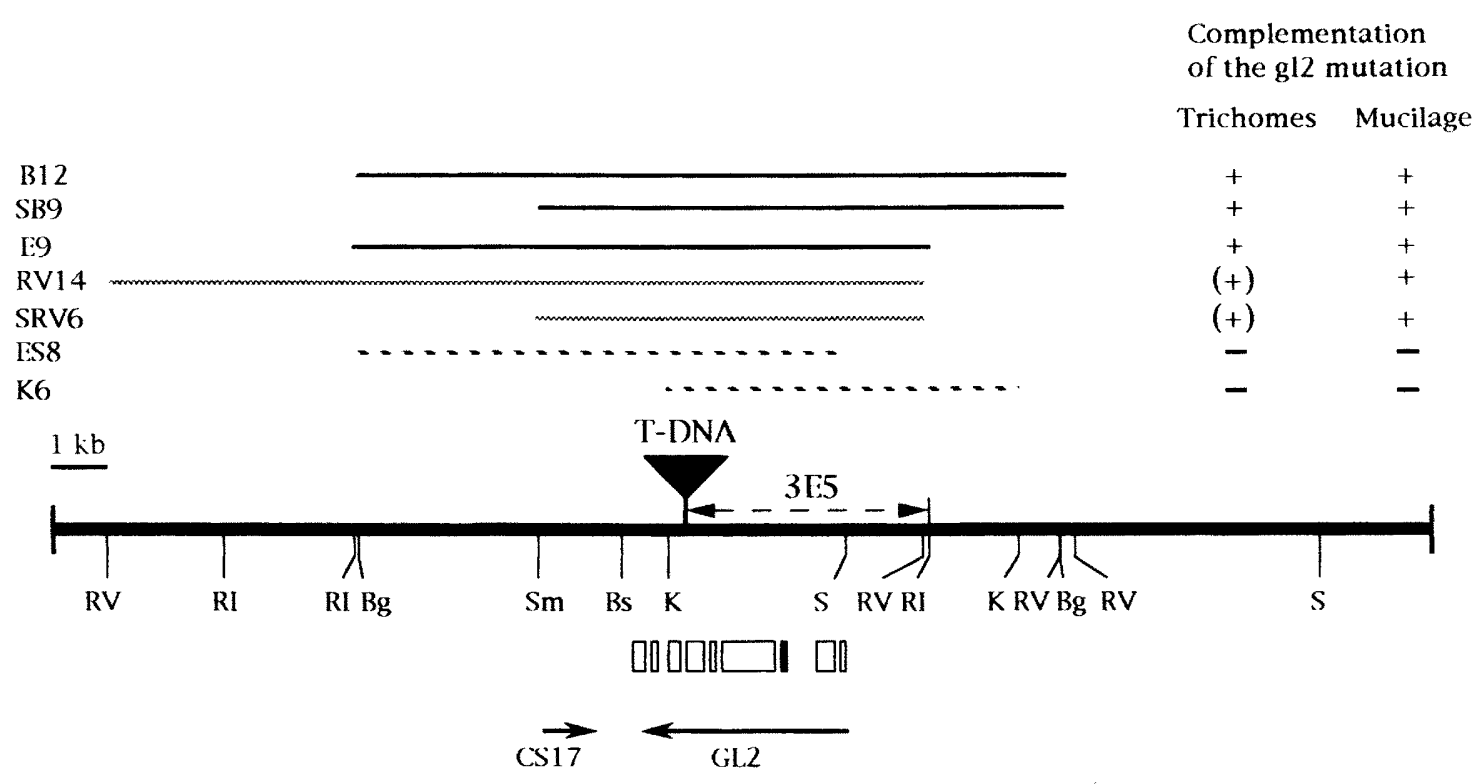

Figure 4. Physical map of the GL2 locus. The position of the T-DNA insert in the gl2-2 mutant is indicated ( $\mathbf{\nabla})$. The genomic fragment rescued by plasmid 3E5 is shown to the right of the T-DNA insert. Fragments selected for complementation experiments are shown above the map, together with the trichome and seed coat mucilage phenotype of g12-3 plants transformed with these fragments. $+=$ Full complementation; $|+|=$ partial complementation; $-=$ no complementation of the $g 12$ phenotype. The location of the GL2 exons are indicated by the rectangles below the map, with the exon encoding the homeo box shown as a solid rectangle. The location and orientation of the chloroplast ribosomal protein gene (CS17) is also shown. Restriction enzyme sites: EcoRV (RV); EcoRI (RI); BglII (Bg); SmaI (Sm); BstXI (Bs); KpnI (K); SalI (S). 
ing $\sim 23 \mathrm{~kb}$ of genomic sequence were used to generate a series of DNA fragments, each tested for its ability to complement the gl2 mutation in transformed plants (Fig. 4). At least five independent transformants from each construct were evaluated.

Plants transformed with the subclones B12 and SB9 showed a normal trichome phenotype and produced seeds with a mucilage coat. In contrast, transformants that carried either the ES8 or the K6 fragments were indistinguishable from the untransformed gl2 mutant. These data indicated that the GL2 gene was located within a 9-kb region delimited by the restriction sites SmaI and BglII (Fig. 4).

We observed that the trichomes on plants transformed with the E9 fragment were less branched when compared with the wild-type trichomes seen on the B12 or SB9 transformants (Figs. 5 and 6A). Deleting an additional $152 \mathrm{bp}$ from the right side of the $\mathrm{E} 9$ fragment reduced the ability of the fragment to restore normal trichome branching to the transformants (Fig. 4). Plants transformed with either the RV14 or SRV6 fragments showed a significantly altered trichome phenotype characterized by a general hypobranched morphology. The majority of trichomes on these plants had only two branches or were simple spikes, which contrast the three branches that are predominantly found on wild-type trichomes (Figs. 5 and 6B). Moreover, many of the trichomes found on these plants initiated branches at atypical positions along the trichome stalk (Fig. 6C,D). Nonetheless, these trichomes
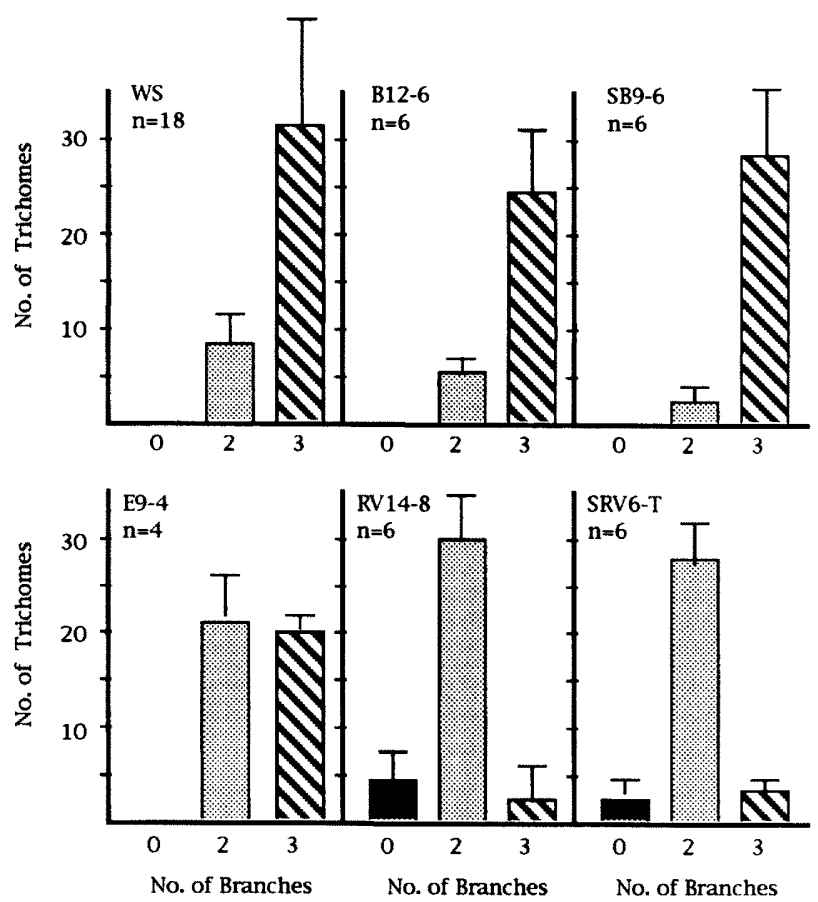

Figure 5. Distribution in the number of branches seen on $A r$ abidopsis trichomes from wild-type and complemented $\mathrm{g} 12 \mathrm{mu}$ tants. Data are presented on a per leaf basis. Only trichomes on the first and second leaves were counted. (n) Total number of leaves counted in the data set.
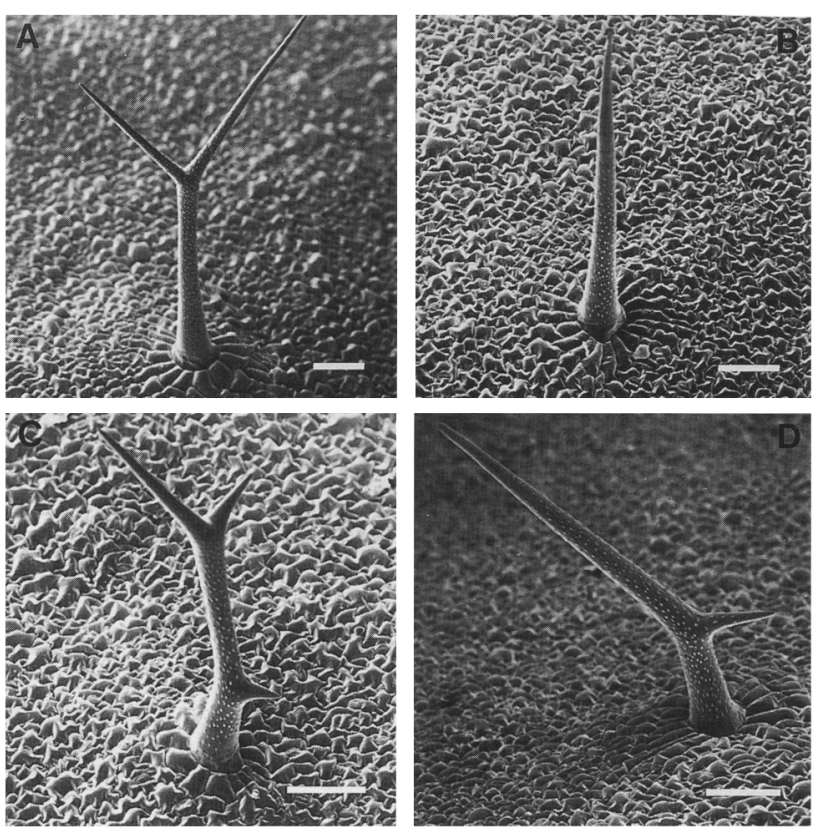

Figure 6. Trichome phenotype of complemented gl2 mutants. Scanning electron micrographs are shown of representative trichomes seen on the leaves of g12-3 mutants transformed with either the E9 $(A)$, or the SRV6 $(B-D)$ fragments. Size bars, $100 \mu \mathrm{m}$.

included the basal support cells and surface papillae noted previously in wild-type trichomes. The altered trichome morphology among these transformants did not include the aborted trichomes characteristic of the $g 12$ phenotype. Finally, all of the RV14- and SRV6-transformed lines produced an apparently normal seed coat mucilage (data not shown).

\section{Sequence analysis of the GL2 gene}

An attempt to identify the GL2 gene by screening a seedling cDNA library was unsuccessful. This result was not unexpected because a GL2 transcript could not be detected by Northern blot analysis using seedling poly $(\mathrm{A})$ RNA. In the absence of a cDNA, the 9-kb genomic DNA fragment from the SmaI site to the BglII site was sequenced (i.e., clone SB9; Fig. 4).

Comparison of potential GL2 open reading frames (ORFs) with sequences in the GenBank and EMBL data bases revealed that one ORF of 50 amino acids had significant identity to the HD sequence. The $\mathrm{HD}$ is a 60 amino-acid motif that is found in a diversity of proteins known to function as transcriptional regulators (Affolter et al. 1990; Gehring et al. 1990). The HD has been highly conserved during evolution as demonstrated by its occurrence in a wide range of metazoans (Laughon 1991); however, only recently have genes encoding the HD been identified in higher plants (Ruberti et al. 1991; Vollbrecht et al. 1991; Mattsson et al. 1992; Schena and Davis 1992; Matsuoka et al. 1993; Schena et al. 1993; Schindler et al. 1993). 
Establishing a potential exon in the genomic sequence allowed PCR primers to be synthesized both within and flanking the homeo box, which in turn were used to amplify progressively larger GL2 cDNAs from seedling RNA. The largest cDNA obtained was 2072 bp, encoding a protein of 660 amino acids, which we believe constitutes the complete GL2 protein (Fig. 7). Three methionine codons in close proximity to each other could serve as the initiating codon for GL2. However, only the second methionine codon occurs within the context of the consensus sequence reported for plant genes (-AACAATGCG-) (Lutcke et al. 1987). The cDNA sequence immediately upstream of the proposed initiation codon includes termination codons in all three ORFs. Similarly, at the $3^{\prime}$ end of the gene, a stop codon is transcribed as part of the distal ORF. In addition, a potential polyadenylation signal occurs in the genomic sequence 72 bp downstream from this termination codon (Fig. 7).

The PCR experiments demonstrated that a GL2 transcript is made from the genomic fragment shown previously to complement the g12 mutation and that the identified homeo box sequence is integral to the gene. Comparison of the cDNA and genomic sequences showed that the GL2 protein is encoded by nine exons with the $\mathrm{HD}$ divided by an intron separating exon 2 and exon 3 (Fig. 4). The amino acid sequence upstream of the GL2 $\mathrm{HD}$ was found to have a high frequency of glutamic and aspartic acid residues (Fig. 7). Acidic domains are known to function as transcriptional activation domains, although they are associated less frequently with HD proteins (Ptashne and Gann 1990; Frankel and Kim 1991).

Several previously isolated homeo box genes in Arabi- dopsis encode a leucine zipper motif immediately downstream from and contiguous with the HD (Ruberti et al. 1991; Mattsson et al. 1992; Schena and Davis 1992). No similar leucine repeat was identified in this region of the GL2 gene. Moreover, it was calculated that the amino acid sequence downstream from the GL2 HD has a low probability of assuming a coiled-coil structure characteristic of the leucine zipper (Lupas et al. 1991).

Sequence analysis of the SB9 clone revealed that in addition to GL2, a nucleus-encoded chloroplast ribosomal protein gene (CS17) was also located on the opposite strand between the SmaI and BstXI sites (Fig. 5). The CS17 gene from Arabidopsis has been cloned previously and sequenced (Gantt and Thompson 1989). This gene does not possess GL2 function as shown by the failure of the ES 8 fragment, which included the complete CS17 gene, to complement the g12 mutation (Fig. 4). We have also sequenced the T-DNA junction in the rescued plasmid 3E5 and established that the insertion disrupted the sixth exon in gl2-2 allele. The genomic sequence from the BstXI site through to the BgIII site (Fig. 4) has been submitted to GenBank (accession no. L32873).

\section{Expression pattern of the GL2 gene}

Since the gl2 mutation affects trichome development, the GL2 expression pattern might be restricted to differentiating protodermal cells. Because trichomes comprise only a small fraction of the total number of cells in the developing leaf, this spatial regulation could explain our inability to detect GL2 message in Arabidopsis seedlings

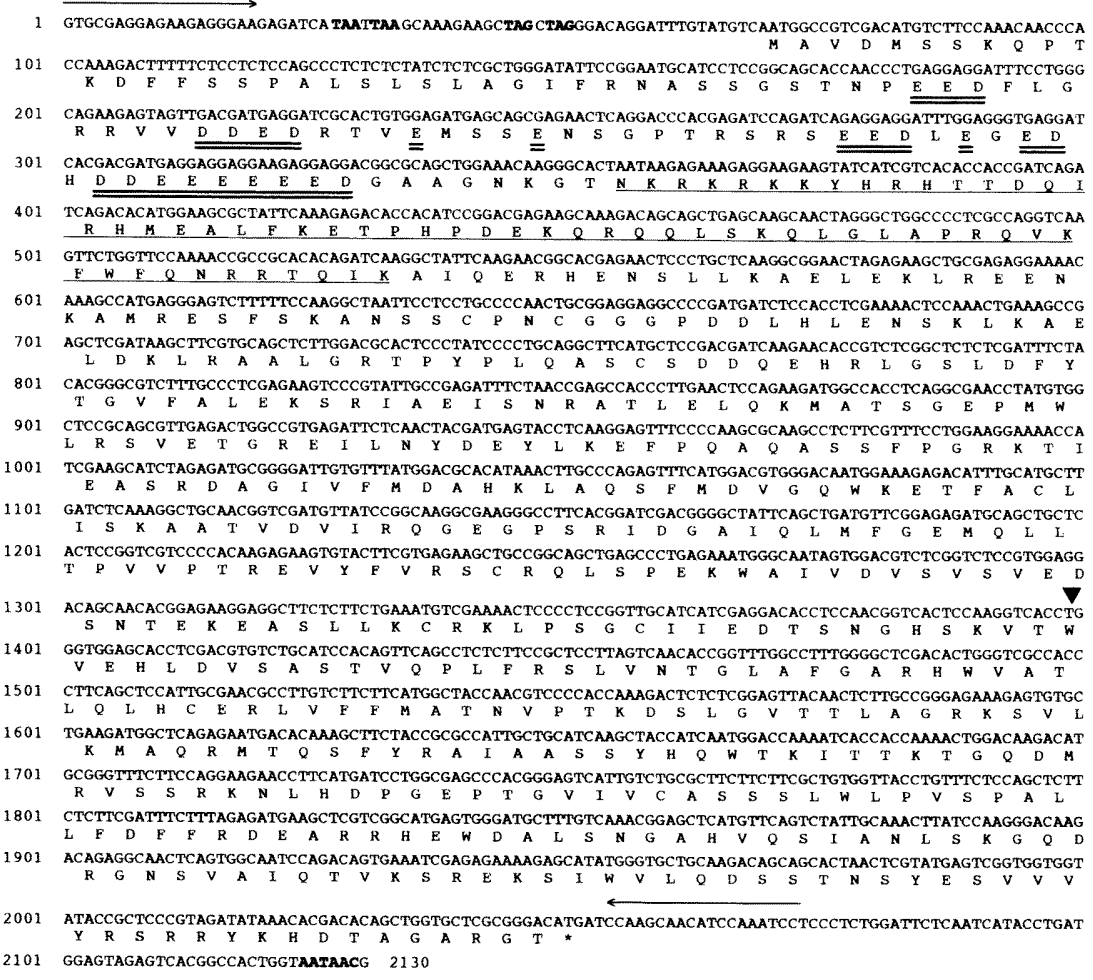

Figure 7. DNA sequence of the GL2 gene and its amino acid translation. The sequence of a full-length GL2 cDNA clone is shown with the amino acid translation given below. The amino acids of the $\mathrm{HD}$ are underlined. Glutamic and aspartic amino acids contributing to the proposed acidic domain are double underlined. Termination codons upstream of the start of translation are shown in boldface type, as is a potential polyadenylation signal at the $3^{\prime}$ end of the sequence. The point of T-DNA insertion in the gl2-2 allele is shown $(\boldsymbol{\nabla})$. The position of the PCR primers used to synthesize the cDNA are indicated by the arrowed lines. 
Figure 8. In situ localization of GL2 mRNA. Longitudinal sections from Arabidopsis seedlings were hybridized to digoxigenin-labeled sense $(A)$ or antisense $(B, C)$ probe as described in Materials and methods.
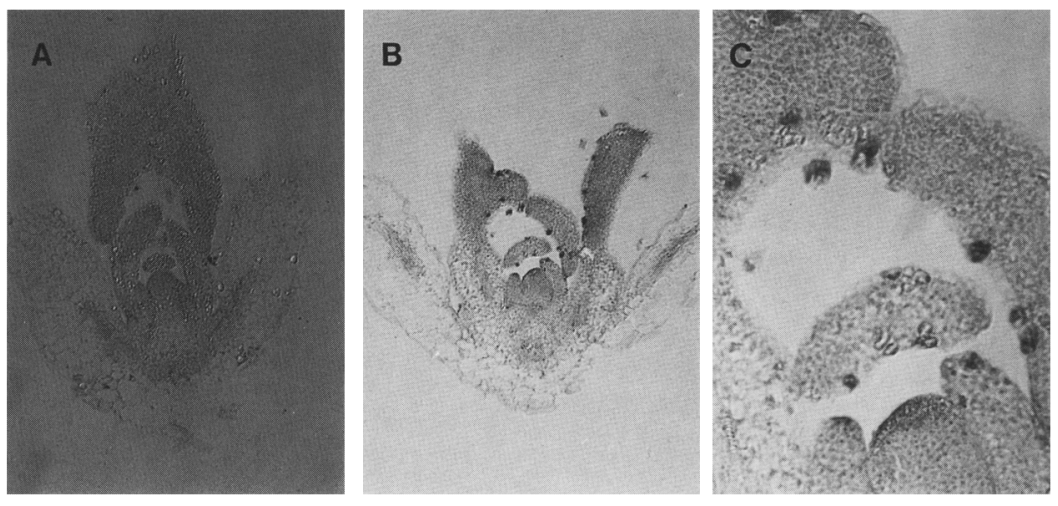

by means other than PCR. To address the question of GL2 expression more closely, we used in situ hybridization to detect GL2 message. Paraffin-embedded seedlings (four-leaf stage) were sectioned longitudinally and hybridized to either sense or antisense strands of a digoxigenin-labeled GL2 sequence. The antisense probe showed a distinct signal in individual developing trichome cells of the emerging leaf primordia not observed with the sense strand probe (Fig. 8).

\section{Discussion}

\section{GL2 is a homeo box gene}

The GL2 gene in Arabidopsis encodes a member of the homeo box family of transcription factors that is expressed in developing trichomes. Homeo box genes encode a highly conserved protein motif, the $\mathrm{HD}$, which functions as a sequence-specific DNA-binding protein (Affolter et al. 1990; Gehring et al. 1990). Structural data from the engrailed and Antenapedia HD proteins from Drosophila indicate that this region is organized into three separate helices, with helix 2 and helix 3 comprising a helix-turn-helix structure characteristic of regulatory proteins in prokaryotes (Kissinger et al. 1990; Otting et al. 1990). The recognition helix 3 is responsible for making DNA base contacts along the major groove of the duplex and includes four highly conserved amino acid residues that serve as a signature for HD proteins. The GL2 gene encodes all four of these amino acids (Tyr-48, Phe-49, Gln-51, and Arg-53) and four of six additional amino acids at other conserved positions along the HD (Fig. 9).

Sequence analysis indicates that animal homeo box genes have diverged into distinct families in the course of evolution, often with genes from different species being represented among a common homeo box family (Laughon 1991). Reduced stringency hybridization using degenerate oligonucleotide probes over the conserved region of helix 3 has shown that like other organisms, Arabidopsis possesses a large number of homeo box genes (Schena and Davis 1992). This approach has been used to clone several of these genes [Athb1(HAT5), Athb2 (HAT4), and Athb3], which show significant structural similarity to one another (Ruberti et al. 1991; Mattsson et al. 1992; Schena and Davis 1992). Their identity extends downstream, beyond their respective HDs to an adjacent leucine zipper motif. A similar juxtaposition of these two motifs has been reported for the Zmhox1a gene, which binds to the shrunken promoter in maize (Bellmann and Werr 1992). Together, these genes define a family of HD proteins unique to plants. DNA-binding activity was used recently to isolate the HAT3.1 gene in Arabidopsis (Schindler et al. 1993). Unlike the HD-ZIP genes, HAT3.1 does not encode a leucine zipper but, rather, exhibits a region with regularly spaced cysteine/
Figure 9. Sequence comparison of HDs from plant homeo box genes. A consensus sequence based on the compiled data of all HD proteins is shown, with large, open arrowheads indicating the most highly conserved amino acids (Laughon 1991). Sequences for GL2 and Knotted-1 have been adjusted to permit maximum alignment to the consensus. Amino acids identical to the GL2 HD are shown as dashes. References: Athb1, Athb2 (Ruberti et al. 1991); HAT4, HAT5 (Schena and Davis 1992); Athb3 (Mattsson et al. 1992); HAT3.1 (Schindler et al. 1993); Knotted-1 (Vollbrecht et al. 1991); Zmhox1a (Bellmann and Werr 1992).

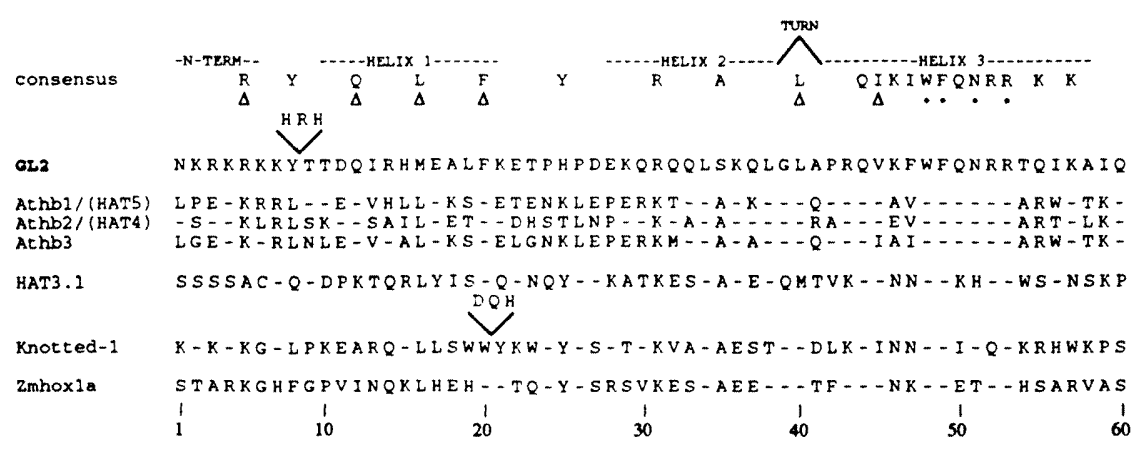


histidine residues characteristic of metal-binding domains, which investigators have termed a PHD-finger (Schindler et al. 1993). Therefore, it is clear that Arabidopsis, like other organisms, encodes structurally distinct families of HD proteins.

On the basis of these structural comparisons, the GL2 gene can also be considered a member of a separate homeo box gene family in Arabidopsis. Whereas the amino acid sequence in the helix-turn-helix region of the GL2 HD shows conservation with the HD-ZIP proteins, the sequence is less well conserved in helix 1 and at the amino terminus, limiting the overall sequence identity to $\sim 40 \%$ (Fig. 9). Structural data indicate that the aminoterminal arm of the HD contributes to sequence-specific contact with DNA in the minor groove and therefore may serve to distinguish target sites among HD proteins that share similar recognition helices (Kissinger et al. 1990; Otting et al. 1990). Such a role may be envisaged for the amino-terminal arm of GL2, which is highly basic in its amino acid content (Fig. 9).

The cDNA indicated that the GL2 homeo box gene encodes neither the PHD-finger motif of the HAT3.1 gene nor the heptad repeat characteristic of the leucine zipper (Landschulz et al. 1988). It has been demonstrated recently that the in vitro DNA-binding of ATHB1 is dependent on the formation of a leucine zipper-mediated homodimer (Sessa et al. 1993). Using the algorithm of Lupas et al. (1991), we estimate the probability is $<1 \%$ that the amino acid sequence downstream from the GL2 $\mathrm{HD}$ adopts a coiled-coil structure. However, it is possible that this region is capable of forming an amphipathic helix that may be important in protein-protein interactions. Although it has been shown that dimerization is not a prerequisite for DNA binding by animal HD proteins, either homo- or heterodimer formation is required for enhanced affinity for the target sequence, as well as for the functional activation of transcription (Affolter et al. 1990; Gehring et al. 1990; Laughon 1991).

The GL2 gene encodes a strongly acidic domain that begins eight amino acids upstream of the homeo box and extends towards the amino terminus of the protein (Fig. 7). Glutamic and aspartic acids account for almost half of the 49 amino acid residues in this region. Acidic domains are known to be involved in protein-protein interactions in the transcriptional activation complex (Ptashne and Gann 1990; Frankel and Kim 1991) and have been noted in other plant HD proteins (Ruberti et al. 1991; Bellmann and Werr 1992).

The inferred size of the GL2 protein is substantially larger than the HD-ZIP proteins of Arabidopsis. The ATHB1 (HAT5) and HAT4 (ATHB2) proteins are 272 and 284 amino acids, respectively, compared with the 660 amino acids determined from the GL2 cDNA (Ruberti et al. 1991; Schena et al. 1993). In this respect, the GL2 gene product is identical in size to the protein encoded by HAT3.1 (Schindler et al. 1993). The homeo box in HAT3.1, however, is situated near the $3^{\prime}$ end of the gene. In contrast, most of the GL2 sequence is located downstream from the homeo box and does not show similarity to sequences in the data base.
The role of GL2 in trichome development

Trichomes derive from meristematic protodermal tissue, initiating early in leaf development as a cell that shows disproportionate enlargement relative to neighboring cells. Once initiated, cell growth is biased in a plane roughly perpendicular to the epidermis. Secondary points of cell wall weakening are then observed which eventually expand outward to form trichome branches. These events proceed without cell division and occur prior to any visible differentiation of guard cells and stomata formation on the leaf lamina. The in situ localization of GL2 transcripts indicated that GL2 expression is associated with these stages of trichome development.

It has been determined that on average, four rounds of DNA endoduplication accompany trichome development (Hülskamp et al. 1994). Furthermore, it has been suggested recently that a direct relationship exists between the DNA content of leaf epidermal cells and their relative age and size (Melaragno et al. 1993). Our observations support those of Hülskamp et al. (1994) that trichomes initiate early in leaf development and thus represent comparatively old cells on the leaf epidermis. Endopolyploidy and cell growth, however, are independent events during trichome morphogenesis, as it has been shown that $g 12$ mutants retain the polyploid levels of wild-type trichomes despite their restricted development (Hülskamp et al. 1994).

The analyses of genetic mosaics suggested previously that the GL2 gene product acts locally on the leaf epidermis (Hülskamp et al. 1994). Our results directly showed that GL2 transcripts are restricted to developing trichomes. The spatial and temporal pattern observed for GL2 transcription is similar to that described for the GL1 gene (Larkin et al. 1993). Plants homozygous for the gl1 mutation do not initiate leaf and stem trichomes (Marks and Feldmann 1989), a phenotype identical to that seen in $t$ tg mutants (Koornneef 1981). Moreover, both the gl1 and the $t \mathrm{tg}$ mutations are epistatic to all other trichome genes, including gl2 (Hülskamp et al. 1994; M. Marks, unpubl.). Therefore, it has been suggested that GL1 and TTG are required for determining cell fate among potential trichome precursor cells (Hülskamp et al. 1994; Larkin et al. 1994). Because GL1 encodes a myb-type transcription factor (Oppenheimer et al. 1991) and TTG is likely to be a homolog of the maize $R$ gene (Lloyd et al. 1992 ), it is possible that the products of these genes directly activate GL2 gene expression as part of the cell's initial commitment to trichome differentiation.

The T-DNA-induced g12 mutation described here $\mid g 12$ 2) showed a curious variety of trichome morphologies, largely dependent on the leaf position examined. The first leaf pair appeared glabrous, except for occasional trichomes that expanded along the leaf surface. Later, rosette leaves showed modest trichome development; however, there was a definite spatial bias in their development. The most severely aborted trichomes were located proximal to the petiole and near the center of the leaf when compared with those trichomes that developed distally and near the leaf perimeter (Fig. 2F). These 
results suggest that the requirement for GL2 in trichome growth may change during leaf development (Hülskamp et al. 1994).

The range of trichome phenotypes observed indicates that while $G L 2$ function is required for normal trichome development, its absence is not sufficient to arrest cell expansion completely. This is likely to represent an inherent redundancy in the molecular events that initiate and perpetuate plant cell growth (Thomas 1993). The propensity for HD proteins to form dimers suggests that other regulatory genes in addition to $G L 2$ may be involved in the activation of cell expansion. The requirement for the $G L 2$ gene product might be only to enhance the expression of genes already transcribed following the protodermal cell's commitment to become a trichome. In this respect, the phenotypes of plants transformed with the clones E9, SRV6, and RV14 may represent a partial restoration of the normal cell expansion pathway. Trichomes developing on these plants showed an intermediate phenotype characterized by the absence of aborted trichomes seen in the gl2-2 mutant, yet produced trichomes that were considered underdeveloped when compared with the fully complemented lines (Fig. 6). These clones represent a deletion of sequence from the $5^{\prime}$ end of the GL2 gene (Fig. 4). The deletions may have removed regulatory elements from the GL2 promoter and attenuated the normal GL2 expression level among developing trichome cells. It is interesting that the trichome morphologies of these partially complemented gl2 mutants represent phenocopies of some trichome branching mutants (e.g., stl, an, sta) (Haughn and Somerville 1988; Hülskamp et al. 1994; Marks and Esch 1994).

GL2 shows both additive and epistatic relationships to several genes that are involved in trichome development. The morphology of the aborted trichomes is unchanged on plants doubly mutant for $g 12$ and stl, dis 1 or dis2. However, the spiked and hypobranched class of trichomes found on gl2 mutants show an additive phenotype in the double mutants (M.D. Marks, unpubl.). Together, these results further the suggestion that there is inherent redundancy in the molecular events that contribute to the trichome's eventual morphology.

\section{Potential gene targets of GL2}

Potential target genes regulated by GL2 expression and their relationship to cell expansion are unknown. Overall trichome development is best considered as surface growth, characteristic of plant parenchyma and epidermal cells. Cell growth is the coordinated result of complex metabolic and biosynthetic processes. These include the perception and transduction of an environmental or developmentally induced signal necessary to stimulate cell expansion, the localized loosening of cell wall components enabling the cell to expand, the maintenance of cell turgor as the cell volume increases, the biosynthesis of a new primary cell wall during growth, and the deposition of secondary cell wall components at the time cell growth is arrested. GL2 could regulate genes involved in any of these diverse processes.

The trichome phenotype of the g12 mutant is characterized not only by aborted growth but also by a loss of growth polarity (Fig. 1D). This was seen as founder cells expanding radially (Fig. 2E), rather than perpendicularly, after initiating growth and suggests that these cells are subject to unrestricted cell wall loosening and intercalation of new cell wall materials. The aberrant branching pattern seen among the partially complemented mutants (Fig. 7D) also suggests that GL2 regulates events associated with cell wall organization during growth.

Cell wall loosening has been closely associated with the "acid growth" theory (Taiz 1984; Cosgrove 1993), and recently, proteins have been identified that induce cell wall extension without its hydrolytic breakdown (McQueen-Mason et al. 1992). Growth polarity is also a function of the cellulose microfibril orientation within the primary cell wall. Their arrangement is generally transverse to the axis of growth and is thought to be governed by the cell's cytoskeleton, particularly the cortical microtubules (Quader et al. 1986; Quader et al. 1987). If GL2 regulates genes required for controlling the position of cortical microtubules, then the loss of GL2 activity could produce an effect similar to microtubule toxins, such as colchicine, that are known to cause normally elongating cells to loose their growth polarity (Taiz 1984). The effect of GL2 on cell wall architecture could also explain the observation that aborted trichomes show a different elemental composition than their normal counterparts, especially with respect to calcium, an element known to impart rigidity to the secondary cell wall (Varner and Lin 1989).

\section{Role of GL2 in the production of the seed coat mucilage}

There is no obvious relationship between the development of trichomes and the accumulation of seed coat mucilage, other than both are regulated by the GL2 locus (Fig. 3). In this regard, gl2 is similar to another trichome mutant, $t$ tg, whose seeds not only lack a seed coat mucilage but also fail to synthesize an anthocyanin pigment within the testa (Koornneef 1981). To our knowledge, there have been no ultrastructure studies on Arabidopsis seed coat development. However, work on other members of the Cruciferae, namely, Raphanus sativus (radish) (Harris 1991) and Brassica campestris (canola) (Van Caeseele et al. 1981), shows that the outer integument differentiates into three cell types: epidermis, parenchyma, and palisade. The parenchyma cells encompass a well-developed endomembrane system and accumulate starch granules within amyloplasts. These cells, however, degenerate as the seed matures, leaving mucilage deposits under the epidermal layer. Therefore, it is assumed that mucilage synthesis represents the remobilization of the parenchyma starch reserves. GL2 and TTG may directly influence the biosynthesis of this polymer or they may be involved in the differentiation of the parenchyma cell layer during integument development. 
With this cell type normally lost during seed maturation, the absence of mucilage could be the only manifestation of the mutation.

\section{Discussion}

In summary, the GL2 gene encodes a HD protein that is distinct in relation to similar genes cloned previously in Arabidopsis. Because the GL2 gene is identified with a mutationally defined locus, we will be able to explore the role of a plant homeo box gene in regulating two dissimilar processes: one relating to the development of leaf and stem trichomes, and the second associated with the differentiating testa. The results demonstrate that at different stages of the plant's life cycle individual transcription factors can be recruited into separate and distinct developmental programs. In the case of trichome development, genes associated with cell growth exhibit somewhat overlapping functions. It will be interesting to establish the specific regulatory role of GL2 in this seemingly complex cell differentiation program.

\section{Materials and methods}

\section{Growth of plants}

A. thaliana ecotype WS seeds were sown on a potting soilvermiculite mix and grown at $20^{\circ} \mathrm{C}$ in growth chambers as described previously (Feldmann and Marks 1987). The generation of T-DNA-tagged lines in Arabidopsis has been described previously (Feldmann 1991). Linkage of the $\operatorname{Kan}^{\mathrm{r}}$ phenotype (TDNA) among segregating T3 gl2 mutant families was determined by scoring $\sim 75-100$ seedlings for kanamycin resistance on agar medium supplemented with kanamycin (Feldmann and Marks 1987). $\mathrm{Kan}^{\mathrm{r}}$ plants were subsequently scored for the recessive gl2 phenotype.

\section{Scanning electron microscopy}

Arabidopsis seedlings grown on soil to the four-leaf stage were harvested and fixed overnight in phosphate-buffered gluteraldehyde $(4 \%)$. The seedlings were dehydrated, subjected to critical point drying, mounted on stubs, and coated with gold; they were then examined by standard methods.

\section{DNA isolation and plasmid rescue}

Genomic DNA was isolated from young Arabidopsis seedlings as described by Weeks et al. (1986). DNA prepared from the homozygous gI2-2 line was used for plasmid rescue of the T-DNA and adjacent genomic sequence as described by Feldmann (1992). Plasmid DNA was prepared from $\sim 40$ rescued $\mathrm{Amp}^{\mathrm{r}}$ colonies, digested with either EcoRI or SalI, and separated on a $0.8 \%$ agarose gel. Two right border rescue clones (3E5 and $5 \mathrm{E} 8$ ) were identified. Restriction maps showed that both plasmids were identical.

\section{Isolation and identification of the GL2 locus}

A genomic library was prepared from Arabidopsis DNA (ecotype WS) partially digested with Sau3A and ligated into the $\lambda$ vector Lambda GEM-11 (Promega), as described by Sambrook et al (1989). A 2.6-kb Xbal fragment of genomic DNA isolated from plasmid $3 \mathrm{E} 5$, was labeled with $\left[{ }^{32} \mathrm{P}\right] \mathrm{dATP}$ and used to screen the library according to conventional procedures (Sambrook et al. 1989|. Restriction enzyme sites of overlapping $\lambda$ clones were mapped with respect to the rescued genomic sequence in plasmid 3E5.

Restriction fragments from the isolated $\lambda$ clones were subcloned into binary vector pBin 19 (Bevan 1984) or p928 (A. Mitra, unpubl.) for transformation of $A$. tumefaciens, strain LBA4404 (Hoekema et al. 1983). Arabidopsis root explants (ecotype WS) from plants homozygous for the gl2-3 allele were transformed with Agrobacterium as described previously (Herman and Marks 1989|. Primary transformants were allowed to self-pollinate, and the progeny were grown in soil to evaluate their trichome morphology independent of tissue culture effects.

\section{DNA sequencing}

The genomic sequence covered by the three $\lambda$ clones was subcloned as several smaller overlapping segments into pBlueScript II SK(+) /Stratagene). Nested deletions were created in the subclones using the exonuclease III procedure of Henikoff (1984). Deletion subclones were sequenced by the University of $\mathrm{Ne}$ braska-Lincoln Center for Biotechnology DNA sequencing facility using the chain termination method of Sanger et al. (1977) and fluorescent primers described by Brumbaugh et al. (1988). DNA sequence analysis and data base searches were done with the University of Wisconsin GCG software package (Devereux et al. 1984). PCR-generated cDNAs were cloned into pGEM-T (Promega) and sequenced as described above.

\section{$R N A$ isolation and $R T-P C R$}

RNA was isolated from Arabidopsis (ecotype WS) seedlings at the four-leaf stage of development as described by Rerie et al. (1991). Synthesis of cDNA and PCR amplification were performed as described by Perkin-Elmer Cetus Corp. (Amplifications, September 1989) from $5 \mathrm{mg}$ of total RNA. The amplification of GL2 cDNA was achieved using the forward and reverse primers shown in Figure 7. PCR conditions were as follows: 2-min denaturation at $95^{\circ} \mathrm{C}$, followed by 40 cycles of 1 min at $95^{\circ} \mathrm{C}, 30 \mathrm{sec}$ at $60^{\circ} \mathrm{C}$, and $2 \mathrm{~min}$ at $72^{\circ} \mathrm{C}$.

\section{In situ hybridization}

In situ probes were obtained from a 900-bp cDNA situated 3' to the homeo box sequence. This fragment was cloned into the HindIII site of pBlueScript II $\mathrm{SK}|+|$ to give $\mathrm{pcHl}$. RNA probes were generated by in vitro transcription of $\mathrm{pcHl}$ incorporating digoxigenin-labeled UTP, as described by Boehringer Manheim. The plasmid linearized with SalI and transcribed by the T3 RNA polymerase generated the antisense strand probe, whereas when linearized by $E c o$ RI and transcribed by the T7 RNA polymerase, the sense strand probe was generated.

Arabidopsis seedlings (ecotype WS) were fixed in paraformaldehyde, dehydrated, and embedded in paraffin as described by Jackson (1991). Sections $(10 \mu \mathrm{m})$ were cut and mounted on polyL-lysine-coated slides and processed following the procedure of Drews et al. (1991), except that BMB blocking reagent (Boehringer Manheim) replaced Denhardt's solution in the hybridization buffer. After washing the slides, the hybridization signal was detected using the chromogenic reagents NBT and X-Phos. The reaction was stopped after $36-48 \mathrm{hr}$ by washing the slides in water.

\section{Acknowledgments}

We thank Deborrah Higuchi for assistance with the molecular complementation experiments and Jeffrey Esch for constructing 
the Arabidopsis genomic library. We acknowledge the gift of the vector p928 from Amitava Mitra. Kit Lee provided expertise with the scanning electron microscopy. We also thank David Oppenheimer and John Larkin for their many helpful comments during the course of this work and in the preparation of the manuscript. This work was supported by a U.S. Department of Agriculture competitive grant (930372) to M.D.M.

The publication costs of this article were defrayed in part by payment of page charges. This article must therefore be hereby marked "advertisement" in accordance with 18 USC section 1734 solely to indicate this fact.

\section{References}

Affolter, M., A. Schier, and W.J. Gehring. 1990. Homeodomain proteins and the regulation of gene expression. Curr. Op. Cell Biol. 2: 485-495.

Bellmann, R. and W. Werr. 1992. Zmhoxla, the product of a novel maize homeobox gene, interacts with the Shrunken 26 bp feedback control element. EMBO J. 11: 3367-3374.

Bevan, M.W. 1984. Binary Agrobacterium vectors for plant transformation. Nucleic Acids Res. 12: 8711-8721.

Brumbaugh, J.A., L.R. Middendorf, and J.L. Grone. 1988. Continuous on-line DNA sequencing using oligonucleotide primers with multiple fluorophores. Proc. Natl. Acad. Sci. 85: $5610-5614$.

Cosgrove, D.J. 1993. How do plant cell walls extend? Plant Physiol. 102: 1-6.

Devereux, J., P. Haeberli, and O. Smithies. 1984. A comprehensive set of sequence analysis programs for the VAX. Nucleic Acids Res. 12: 387-395.

Drews, G.N., J.L. Bowman, and E.M. Meyerowitz. 1991. Negative regulation of the Arabidopsis homeotic gene $A G A$ MOUS by APETELA2 product. Cell 65: 991-1002.

Ehkeringer, J. 1984. Ecology and ecophysiology of leaf pubescence in North American desert plants. In Biology and chemistry of plant trichomes (ed. E. Rodriguez, P.L. Healey, and I. Mehta), pp. 113-132. Plenum Press, New York.

Feldmann, K.A. 1991. T-DNA insertional mutagenesis in Arabidopsis: Mutational spectrum. Plant J. 1: 71-82.

1992. T-DNA insertion mutagenesis in Arabidopsis: Seed infection/transformation. In Methods in Arabidopsis research (ed. C. Koncz, N.-H. Chua, and J. Schell), pp. 274 289. World Scientific, London, UK.

Feldmann, K.A. and M.D. Marks. 1987. Agrobacterium-mediated transformation of germinating seeds of Arabidopsis thaliana: A nontissue culture approach. Mol. \& Gen. Genet. 208: 1-9.

Frankel, A.D. and P.S. Kim. 1991. Modular structure of transcription factors: Implications for gene regulation. Cell 65: 717-719.

Gantt, J.S. and M.D. Thompson. 1989. Plant cytosolic ribosomal protein S11 and chloroplast ribosomal protein CS17: Their primary structures and evolutionary relationships. $/$. Biol. Chem. 265: 2763-2767.

Gehring, W.J., M. Muller, M. Affolter, A. Percival-Smith, M. Billeter, Y.Q. Qian, G. Otting, and K. Wuthrich. 1990. The structure of the homeodomain and its functional implications. Trends Genet. 6: 325-329.

Gómez-Campo, C. and M.E. Tortosa. 1974. The taxonomic and evolutionary significance of some juvenile characters in the Brassiceae. Bot. J. Linn. Soc. 69: 105-124.

Harris, W.M. 1991. Seed coat development in radish (Raphnus sativus L.). Phytomorphology 41: 34-1-349.

Haughn, G.W. and C.R. Somerville. 1988. Genetic control of morphogenesis in Arabidopsis. Dev. Genet. 9: 73-89.
Henikoff, S. 1984. Unidirectional digestion with exonuclease III creates targeted break points for DNA sequencing. Gene 28: 351-359.

Herman, P.L. and M.D. Marks. 1989. Trichome development in Arabidopsis thaliana. II. Isolation and complementation of the Glabrous1 gene. Plant Cell 1: 1051-1055.

Hoekema, A., P.R. Hirsch, P.J.J. Hooykass, and R.A. Schilperoort. 1983. A binary plant vector strategy based on separation of vir- and T-region of the Agrobacterium tumefaciens Tiplasmid. Nature 303: 179-180.

Hülskamp, M., S. Misera, and G. Jürgens. 1994. Genetic dissection of trichome cell development in Arabidopsis. Cell 76: 555-566.

Jackson, D. 1991. In situ hybridization in plants. In Molecular plant pathology: A practical approach (ed. D.J. Bowles, S.J. Gurr, and M. McPherson), pp. 163-174. Oxford University Press.

Kissinger, C.R., L. Beishan, E. Martin-Blanco, T.B. Kornberg, and C.O. Pabo. 1990. Crystal structure of an engrailed homeodomain-DNA complex at $2.8 \AA$ resolution: A framework for understanding homeodomain-DNA interactions. Cell 63: 579-590.

Koornneef, M. 1981. The complex syndrome of ttg mutants. Arabidopsis Inf. Serv. 18: 45-51.

Koornneef, M., L.W.M. Dellaert, and J.H. van der Veen. 1982. EMS- and radiation induced frequencies at individual loci in Arabidopsis thaliana (L.) Heynh. Mutat. Res. 93: 109-123.

Landschulz, W.H., P.F. Johnson, and S.L. McKnight. 1988. The leucine zipper: A hypothetical structure common to a new class of DNA binding proteins. Science 240: 1759-1764.

Larkin, J.C., D.G. Oppenheimer, S. Pollock, and M.D. Marks. 1993. Arabidopsis GLABROUS1 gene requires downstream sequences for function. Plant Cell 5: 1739-1748.

Larkin, J.C., D.G. Oppenheimer, A.M. Lloyd, E.T. Paparozzi, and M.D. Marks. 1994. The roles of GLABROUS1 and TRANSPARENT TESTA GLABRA genes in the trichome developmental pathway of Arabidopsis thaliana. Plant Cell (in press).

Laughon, A. 1991. DNA binding specificity of homeodomains. Biochemistry 30: 11357-11367.

Lloyd, A.M., V. Walbot, and R.W. Davis. 1992. Arabidopsis and Nicotiana anthocyanin production activated by maize regulators R and Cl. Science 258: 1773-1775.

Lupas, A., M. Van Dyke, and J. Stock. 1991. Predicting coiled coils from protein sequence. Science 252: 1162-1164.

Lutcke, H.A., K.C. Chow, F.S. Mickel, K.A. Moss, H.F. Kern, and G.A. Scheele. 1987. Selection of AUG initiation codons differs in plants and animals. EMBO I. 6: 43-48.

Marks, M.D. and J.J. Esch. 1992. Trichome formation in Arabidopsis as a genetic model for studying cell expansion. Curr. Top. Plant Biochem. Physiol. 11: 131-142.

-1994. Morphology and development of mutant and wildtype trichomes on the leaves of Arabidopsis thaliana. In Arabidopsis: An atlas of morphology and development (ed. J. Bowman), Springer-Verlag, Berlin, Germany (In press.)

Marks, M.D., J. Esch, P. Herman, S. Sivakumaran, and D. Oppenheimer. 1991. A model for cell-type determination and differentiation in plants. In Molecular biology of plant development (ed. G. Jenkins and W. Schuch), pp. 77-87. Company of Biologists Limited, Cambridge, UK.

Marks, M.D. and K.A. Feldmann. 1989. Trichome development in Arabidopsis thaliana. I. T-DNA tagging of the Glabrous1 gene. Plant Cell 1: 1043-1050.

Matsuoka, M., H. Ichikawa, A. Saito, Y. Tada, T. Fujimura, and Y. Kano-Murakami. 1993. Expression of a rice homeobox gene causes altered morphology of transgenic plants. Plant Cell 5: 1039-1048. 
Mattsson, J., E. Soderman, M. Svenson, C. Borkird, and P. Engstrom. 1992. A new homeobox-leucine zipper gene from Arabidopsis thaliana. Plant Mol. Biol. 18: 1019-1022.

McQueen-Mason, S., D.M. Durachko, and D.J. Cosgrove. 1992. Two endogenous proteins that induce cell wall extension in plants. Plant Cell 4: 1425-1433.

Melaragno, J.E., B. Mehrotra, and A.W. Coleman. 1993. Relationship between endopolyploidy and cell size in epidermal tissue of Arabidopsis. Plant Cell 5: 1661-1668.

Nyman, Y. 1993. The pollen-collecting hairs of Campanula (Campanulaceae). I. Morphological variation and the retractive mechanism. Am. J. Bot. 80: 1427-1436.

Oppenheimer, D.G., P.L. Herman, S. Sivakumaran, J. Esch, and M.D. Marks. 1991. A myb gene required for leaf trichome differentiation in Arabidopsis is expressed in stipules. Cell 67: 483-493.

Oppenheimer, D.G., J. Esch, and M.D. Marks. 1992. Molecular genetics of Arabidopsis trichome development. In Control of plant gene expression (ed. D.P.S. Verma), pp. 275-286. CRC Press, Boca Raton, FL.

Otting, G., Y.Q. Qian, M. Billiter, M. Muller, M. Affolter, W. Gehring, and K. Wuthrich. 1990. Protein-DNA contacts in the structure of a homeodomain-DNA complex determined by nuclear magnetic resonance spectroscopy in solution. EMBO I. 9: 3085-3092.

Ptashne, M. and A.A.F. Gann. 1990. Activators and targets. Nature 346: 329-331.

Quader, H., G. Deichgraber, and E. Schnepf. 1986. The cytoskeleton of Cobaea seed hairs: Patterning during cell-wall differentiation. Planta 168: 1-10.

Quader, H., W. Herth, U. Ryser, and E. Schnepf. 1987. Cytoskeletal elements in cotton seed hair development in vitro: Their possible regulatory role in cell wall organization. Protoplasma 137: 56-62.

Rerie, W.G., M.I. Whitecross, and T.G.V. Higgins. 1991. Developmental and environmental regulation of pea legumin genes in transgenic tobacco. Mol. Gen. Genet. 225: 148-157.

Rick, C.M. 1947. Partial suppression of hair development indirectly affecting fruitfulness and the proportion of cross-pollination in a tomato mutant. Am. Nat. 81: 185-202.

Ruberti, I., G. Sessa, S. Lucchetti, and G. Morelli. 1991. A novel class of plant proteins containing a homeodomain with a closely linked leucine zipper motif. EMBO /. 10: 1787-1791.

Sambrook, J., E.F. Fritsch, and T. Maniatis. 1989. Molecular cloning: A laboratory manual. Cold Spring Harbor Laboratory Press, Cold Spring Harbor, New York.

Sanger, F., S. Nicklin, and A.R. Coulson. 1977. DNA sequencing with chain-terminating inhibitors. Proc. Natl. Acad. Sci. 72: 5463-5467.

Schena, M. and R.W. Davis. 1992. HD-Zip proteins: Members of an Arabidopsis homeodomain protein superfamily. Proc. Natl. Acad. Sci. 89: 3894-3898.

Schena, M., A.M. Lloyd, and R.W. Davis. 1993. The HAT4 gene of Arabidopsis encodes a developmental regulator. Genes \& Dev. 7: 367-379.

Schindler, U., H. Beckmann, and A.R. Cashmore. 1993. HAT3.1, a novel Arabidopsis homeodomain protein containing a conserved cysteine-rich region. Plant J. 4: 137-150.

Sessa, G., G. Morelli, and I. Ruberti. 1993. The Athb-1 and -2 HD-Zip domains homodimerize forming complexes of different DNA binding specificities. EMBO I. 12: 3507-3517.

Taiz, L. 1984. Plant cell expansion: Regulation of cell wall mechanical properties. Annu. Rev. Plant Physiol. 35: 585-657.

Thomas, J.H. 1993. Thinking about genetic redundancy. Trends Genet. 9: 395-399.

Van Caeseele, L., J.T. Mills, M. Sumner, and R. Gillespie. 1981.
Cytology of mucilage production in the seed coat of Candle canola (Brassica campestris). Can. J. Bot. 59: 292-300.

Varner, J.E. and L.-S. Lin. 1989. Plant cell wall architecture. Cell 56: 231-239.

Vermeer, J. and R.L. Peterson. 1979. Glandular trichomes on the inflorescence of Chrysanthemum morifolium cv. Dramatic (Compositae). I. Development and morphology. Can. J. Bot. 57: 705-713.

Vollbrecht, E., B. Veit, N. Sinha, and S. Hake. 1991. The developmental gene Knotted-1 is a member of a maize homeobox gene family. Nature 350: 241-243.

Wagner, G.J. 1991. Secreting glandular trichomes: More than just hairs. Plant Physiol. 96: 675-679.

Weeks, D.P., N. Beerman, and O.M. Griffith. 1986. A smallscale five hour procedure for islolation of multiple samples of CsCl-purified DNA: Application to isolation from mammalian, insect, higher plant, algae, yeast and bacterial sources. Anal. Biochem. 152: 376-385. 


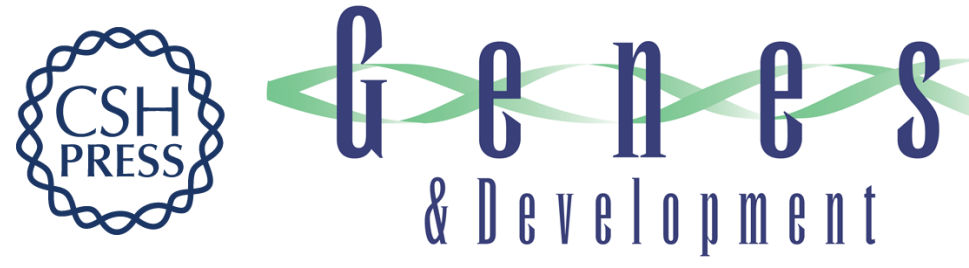

\section{The GLABRA2 gene encodes a homeo domain protein required for normal trichome development in Arabidopsis.}

W G Rerie, K A Feldmann and M D Marks

Genes Dev. 1994, 8:

Access the most recent version at doi:10.1101/gad.8.12.1388

References This article cites 56 articles, 14 of which can be accessed free at:

http://genesdev.cshlp.org/content/8/12/1388.full.html\#ref-list-1

License

Email Alerting

Service right corner of the article or click here.

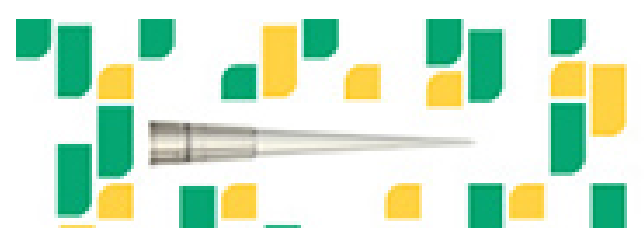

Focused on your science. 